\title{
In Vitro Propagation of Cydonia oblonga cv. SKAU-016
}

\author{
Yusra Ali Basu*, M.A. Mir, K.M. Bhatt and B.A. Mir \\ Sher-e-Kashmir University of Agricultural Sciences and Technology of Kashmir, \\ Shalimar, Srinagar - 191 121, India \\ *Corresponding author
}

\begin{tabular}{|c|c|}
\hline & A B S T R A C T \\
\hline & re surface sterilized with different sterilant regimes and \\
\hline Keywords & $\begin{array}{l}\text { incubated under normal culture room conditions. Satisfactory culture asepsis }(55.99 \%) \\
\text { and explant survival }(56.66 \% \text { ) was achieved in forced explants by subjecting them to the }\end{array}$ \\
\hline $\begin{array}{l}\text { Aseptic culture, in } \\
\text { vitro propagation, in } \\
\text { vitro rooting, }\end{array}$ & $\begin{array}{l}\text { treatment of } 0.1 \text { per cent Mercuric chloride for } 10 \text { minutes followed by } 70 \text { per cent ethyl } \\
\text { alcohol for } 10 \text { seconds. Murashige and Skoog's full strength medium with } 0.50 \mathrm{mg} / 1 \mathrm{BAP}\end{array}$ \\
\hline $\begin{array}{l}\text { Proliferation, } \\
\text { Quince, Tissue } \\
\text { culture. }\end{array}$ & $\begin{array}{l}\text { and } 0.01 \mathrm{mg} / \mathrm{l} \text { IBA gave the best response in terms of establishment of cultures. Murashige } \\
\text { and Skoog's full strength basal media supplemented with BAP and IBA at different } \\
\text { concentrations were tried for culture proliferation of quince and it was found that BAP at }\end{array}$ \\
\hline Article Info & Shoot number/explants $(5.75 \mathrm{~cm})$ and maximum shoot length $(5.49 \mathrm{~cm})$. However, the lowest \\
\hline $\begin{array}{l}\text { Accepted: } \\
21 \text { August } 2017 \\
\text { Available Online: } \\
\text { 10 September } 2017\end{array}$ & $\begin{array}{l}\text { percentage of proliferated cultures }(41.66 \%) \text { were observed in WPM medium } \\
\text { supplemented with BAP } 0.50 \mathrm{mg} / \mathrm{l} \text { and IBA } 0.01 \mathrm{mg} / \mathrm{l} \text {. Microcuttings }(10-15 \mathrm{~mm}) \text { from the } \\
\text { proliferated cultures were inoculated in two media supplemented with different IBA } \\
\text { concentrations for rooting.MS medium fortified with IBA }(1.25 \mathrm{mg} / \mathrm{l}) \text { resulted in maximum } \\
\text { rooting }(81.66 \%) \text {, root number/shoot }(5.00 \%) \text { and root length }(6.15 \mathrm{~cm}) \text {. }\end{array}$ \\
\hline
\end{tabular}

\section{Introduction}

Quince (Cydonia oblonga Mill.) is grown in all the temperate zones of the world. Major producing areas of world are Turkey, USA, New York, Europe, New Zealand, Brazil and J\&K (Chadha, 2001). Turkey ranks first in the world quince production by producing the quarter of the total world's production. The total area under quince cultivation is about $3.96 \mathrm{~m}$ ha. In India, Quince is mostly grown in $\mathrm{J} \& \mathrm{~K}$ and some parts of H.P. The principal cultivars grown in other parts of the world are Orange, Champion, Vandeman, Portugal, Smyrna and Pineapple (Ahmad et al., 2004). The usual method of propagation of quince is by rooting of cuttings or layering which is very cumbersome, season dependent and time consuming. The traditional methods of propagation are proving inadequate to cope with the increasing demand of the planting material of desired genotypes.

Micro propagation is the only alternative technique for increasing the supply of quality planting material. In Quince, micropropagation was achieved for the first time in 1986. Since these first reports, significant progress has been made in the different areas of in vitro culture of Quince (Anirudh et al., 2008; Giorgota et al., 2009). In view of importance of Quince in the state 
economy and need for its rapid multiplication, the present investigation was laid to develop a commercial micropropagation protocol of Cydonia oblonga mill cv.SKAU-016.

\section{Materials and Methods}

Present investigations were carried out at the Biotechnology Laboratory of the Division of Fruit Science, SKUAST-K during the year 2010-2012.Hardwood cuttings were collected from the mature standing stock plants of SKAU-016 selection of quince in open field from the inception of dormancy during NovDec. For forcing dormant cuttings (terminal or subterminal) of $15-20 \mathrm{~cm}$ length $(10-15 \mathrm{~mm}$ diameter) were collected from mature quince trees. The cuttings were treated with 0.2 per cent Captan and stored in a cool store at $4 \pm 3^{\circ} \mathrm{C}$ in polythene bags until use. Cuttings were taken out of the cold storage after 45 days and placed in glass jars filled with distilled water after recutting there base. Cuttings were kept in incubation chamber maintained at $24 \pm 1^{\circ} \mathrm{C}$ under the photoperiod of 16 hour light and 8 hour darkness with light intensity of 3.5 plus. Sprouting of buds took place within 15-20 days (Fig. 1). Shoots put forth by these sprouted buds served as forced explants source. Unforced explants were obtained from field grown mature trees of quince. Shoot tips collected from forced and unforced explants sources were surface sterilized with different sterilants, alone or in combinations. Surface sterilized explants were rinsed 4-5 times with double distilled sterile water, prepared and cultured in MS basal medium. The $\mathrm{pH}$ of the medium was adjusted to 5.7. Healthy explants were transferred onto fresh media on establishment studies using two different media, viz., Murashige and Skoog's and Woody Plant Medium supplemented with different growth regulators. Data relating to establishment and explants necrosis were recorded after $4 \pm 1$ week of culture inoculation.
Well established cultures were transferred to fresh proliferation media fortified with different levels of growth regulators. Data pertaining to per cent proliferated cultures, number and length of shoots /explants were recorded after $4 \pm 1$ weeks of inoculation in the proliferation media. Microshoots (10-15 mm) from proliferating cultures were aseptically excised and transferred to different media fortified with various concentrations of IBA for rooting. Rooting per cent, root number and root length were recorded after $4 \pm 1$ weeks of inoculation in the rooting media. The experiments were carried out using completely randomized design with 20 explants /treatment and replicated thrice. Observations with regard to established and callused cultures were made within $4 \pm 1$ weeks of inoculation in the establishment media. Data was statistically analysed using Mini-Tab-Statistical package.

To satisfying model assumptions of experiments, percentages data was subjected to angular/square root transformations as suggested by Steel and Torrie (1981).

\section{Results and Discussion}

Forced and unforced, shoot tip explants were subjected to five different sterilization regimes using MS as the basal medium. Effects of various sterilization regimes and forcing on culture asepsis and survival were highly significant (Table 1).

Highest mean percentage of aseptic cultures to the tune of 64.99 per cent was obtained under the $\mathrm{S}_{5}$ sterilization regime $\left(0.1 \% \mathrm{HgCl}_{2}\right.$ for 10 minutes followed by $70 \%$ ethyl alcohol for 10 seconds) followed by 56.66 per cent under $\mathrm{S}_{4}$ sterilization regime $(10 \%$ sodium hypochlorite for 10 minutes followed by $70 \%$ ethyl alcohol for 10 seconds), whereas the lowest mean percentage of aseptic cultures to the tune of 37.49 per cent was obtained by 
treating the explants with $\mathrm{S}_{3}$ sterilization regime (70\% ethyl alcohol for 10 seconds). Explant source had a significant influence upon culture asepsis. Maximum mean percentage of aseptic cultures of 55.99 per cent was observed when the forced explants were utilized as against 43.33 per cent when the plants were obtained from field grown donor stock plants. Main effects due to different sterilization regimes and forcing on survival of explants was statistically significant. Maximum mean survival of explants $(62.49 \%)$ was obtained under $\mathrm{S}_{2}$ sterilization regime where mercuric chloride was applied at 0.1 per cent for 10 minutes followed by $S_{1}$ sterilization regime $(54.99 \%)$ where sodium hypochlorite at a concentration of $10 \%$ was used for 10 minutes, whereas the lowest mean survival of 39.16 per cent was obtained under $S_{5}$ sterilization regime in which mercuric chloride was used at $0.1 \%$ for 10 minutes followed by treating the explants with 70 per cent ethyl alcohol for 10 seconds. However the highest mean survival of 56.66 per cent was obtained in case of forced explants as against 41.99 per cent when unforced explants were utilized.

Though $\mathrm{S}_{5}$ treatment resulted in maximum per cent aseptic cultures but the survival percentage was less because this treatment resulted in the necrosis and injury of the explants where $S_{2}$ treatment resulted in less percentage of aseptic cultures but the survival rate was higher as most of workers have found that a single sterilant is more effective than the combinations in increasing explant survival. These results are in close conformity with those of Dalal et al., (1992) in grape, Modgil et al., (1994) in apple, Hammerschlag (1980) in peach, Norton and Norton (1986) in Prunus species, and Muna et al., (1999) in cherry. Higher culture asepsis and explant survival with forced explants is attributed to the fact that forced explants were developed from the cuttings incubated in the growth chamber and hence had relatively lesser disease inoculums compared to unforced explants taken from the stock plants grown in the open field conditions. Similar results were reported by the Dalal et al., (2000) with forced explants of different crops.

\section{Culture establishment}

The first step of initiating in vitro culture is to successfully adapt the plant tissue or explants to heterotrophic mode of nutrition. This has been termed as establishment stage (Murashige, 1974). The culture establishment medium is useful for conditioning the explants and for stimulating its initial growth (Fig. 2). Effect of media, different hormonal concentrations and forcing on establishment cultures was observed statistically significant (Table 3).

Maximum mean establishment percentage of $50.54 \%$ was achieved when the explants were cultured in MS medium $\left(\mathrm{M}_{1}\right)$ under forced conditions followed by 47.21 per cent under unforced conditions. However the lowest mean establishment percentage of 37.76 per cent was achieved when the explants were cultured in Lloyd and McCown $\left(\mathrm{M}_{2}\right)$ medium under unforced conditions

The variations in response of explants of SKAU-016 selection to different types of media supplemented with different growth regulators in terms of establishment may be due to the reason that these media contain different concentration of nutrients which may or may not suit to explants during initial stages. Requirement of growth hormones is also specific for different tissues due to the endogenous levels of hormones in different tissues. Regarding the main effects of growth regulators, over all establishment percentage was increased when cytokinin and auxin were used in combination. However when cytokinin (BAP) was used alone, percentage 
of establishment was declined. Considering the effects of various treatment combinations of cytokinins and auxins, the treatment combination of BAP at $0.50 \mathrm{mg} \mathrm{l}^{-1}$ and IBA $0.01 \mathrm{mg} \mathrm{l}^{-1}$ resulted in highest establishment percentage of 81.66 , followed by 62.49 per cent when the cytokinin (BAP) was used alone at a dosage level of $0.50 \mathrm{mg} \mathrm{l}^{-1}$ whereas the lowest percentage of establishment 21.66 was obtained when the BAP concentration was increased from $0.50 \mathrm{mg} \mathrm{l}^{-1}$ to $0.75 \mathrm{mg} \mathrm{l}^{-1}$ without any addition of auxin. The interaction effect was non-significant.

Requirement of growth hormones varies considerably with the nature of tissue because of endogenous hormonal levels in different tissues (Bhojwani, 1990). These observations are in accordance with Morini and Sciutli (1991), who found that shoot tips of quince cultivar established best on MS medium supplemented with $0.08 \mathrm{mg} \mathrm{l}^{-1} \mathrm{IBA}, 0.8 \mathrm{mg} \mathrm{l}^{-1}$ $\mathrm{BA}$, and $0.1 \mathrm{mg} \mathrm{l}^{-1} \mathrm{GA}_{3}$. Similar findings were also observed by Gulsen and Dumanoglu
(1991) they observed that shoot tips of quince cultivar established best on MS medium supplemented with $3.0 \mathrm{mg} \mathrm{l}^{-1} \mathrm{BA}, 0.1 \mathrm{mg} \mathrm{l}^{-1}$ IAA, $0.1 \mathrm{mg}^{-1} \mathrm{GA}_{3}$. Effect of various sterilization regimes and forcing on necrotic cultures was highly significant (Table 2). Highest mean percentage of necrotic cultures to the tune of 56.66 per cent was obtained under $\mathrm{S}_{5}$. Sterilization regime $\left(0.1 \% \mathrm{HgCl}_{2}\right.$ for 10 minutes followed by $70 \%$ ethyl alcohol for 10 seconds) followed by 49.99 per cent under $\mathrm{S}_{4}$ sterilization regime $(10 \%$ sodium hypochlorite for 10 minutes followed by $70 \%$ ethyl alcohol for 10 seconds) whereas the lowest mean percentage of necrotic cultures to the tune of 37.49 per cent was obtained by treating the explants with $\mathrm{S}_{2}$ sterilization regime $\left(0.1 \% \mathrm{HgCl}_{2}\right.$ for 10 minutes $)$. As regards, the main effects of forcing, maximum mean percentage of necrotic cultures of 57.99 per cent was observed when the forced explants were utilized as against 34.33 per cent when the explants were obtained from field grown donor stock plants.

Table.1 Influence of various sterilants on culture asepsis (per cent aseptic cultures) \& survival (\%) in forced \& unforced explants of quince cv.SKAU-016

\begin{tabular}{|c|c|c|c|c|c|c|}
\hline & $\begin{array}{r}\text { Cultur } \\
\text { Expl } \\
\end{array}$ & $\begin{array}{l}\text { is }(\%) \\
\text { urce }\end{array}$ & & $\begin{array}{r}\text { Explant } \\
\text { Expl } \\
\end{array}$ & $\begin{array}{l}1 \%) \\
\text { ce }\end{array}$ & \\
\hline Sterilants & Unforced & Forced & Mean & Unforced & Forced & Mean \\
\hline $\mathrm{S}_{1}$ & 33.33 & 51.66 & 42.49 & 46.66 & 63.33 & 54.99 \\
\hline $\mathrm{S}_{2}$ & 39.99 & 53.33 & 46.66 & 48.33 & 76.66 & 62.49 \\
\hline $\mathrm{S}_{3}$ & 28.33 & 46.66 & 37.49 & 43.33 & 54.99 & 49.16 \\
\hline $\mathrm{S}_{4}$ & 54.99 & 58.66 & 56.66 & 36.66 & 44.99 & 40.83 \\
\hline $\mathrm{S}_{5}$ & 59.99 & 69.99 & 64.99 & 34.99 & 43.33 & 39.16 \\
\hline Mean & 43.33 & 55.99 & & 41.99 & 56.66 & \\
\hline$C D(p \leq 0.05)$ & & & & & & \\
\hline Main effect of S & & & 1.26 & & & 1.60 \\
\hline Main effect of $\mathrm{E}$ & & & 2.00 & & & 2.53 \\
\hline Sterilants x Exp & & & 2.83 & & & 3.59 \\
\hline
\end{tabular}


Int.J.Curr.Microbiol.App.Sci (2017) 6(9): 1865-1873

\begin{tabular}{|c|c|c|c|c|c|c|c|c|c|c|c|c|c|c|c|}
\hline \multirow{3}{*}{\begin{tabular}{l}
\multicolumn{1}{c}{ Media } \\
Explant \\
Growth Regutator \\
BAP+IBA $(\mathrm{mg} / \mathrm{l})$
\end{tabular}} & \multicolumn{5}{|c|}{ Proliferating cultures (\%) } & \multicolumn{4}{|c|}{ Number of shoots / Explant } & \multicolumn{6}{|c|}{ Shoot Length (cm) } \\
\hline & \multicolumn{2}{|c|}{ M1 } & \multicolumn{2}{|c|}{ M2 } & \multirow[b]{2}{*}{ Mean } & \multicolumn{2}{|c|}{ M1 } & \multicolumn{2}{|c|}{ M2 } & \multicolumn{3}{|c|}{ M1 } & \multicolumn{2}{|c|}{ M2 } & \multirow[b]{2}{*}{ Mean } \\
\hline & $\mathbf{E}_{1}$ & $\mathbf{E}_{2}$ & $\mathbf{E}_{1}$ & $\mathbf{E}_{2}$ & & $\mathbf{E}_{1}$ & $\mathbf{E}_{2}$ & $\mathbf{E}_{1}$ & $\mathbf{E}_{1}$ & Mean & $\mathbf{E}_{1}$ & $\mathbf{E}_{2}$ & $\mathbf{E}_{1}$ & $\mathbf{E}_{2}$ & \\
\hline 0.25 & $\begin{array}{l}20.00 \\
(4.48)\end{array}$ & $\begin{array}{l}30.00 \\
(5.51)\end{array}$ & $\begin{array}{l}16.66 \\
(4.16)\end{array}$ & $\begin{array}{l}20.00 \\
(4.48)\end{array}$ & 21.66 & 5.03 & 5.10 & 5.03 & 2.20 & 5.07 & 2.20 & 2.50 & 1.60 & 1.90 & 2.05 \\
\hline 0.50 & $\begin{array}{l}50.00 \\
(7.11)\end{array}$ & $\begin{array}{l}56.66 \\
(7.58)\end{array}$ & $\begin{array}{l}43.33 \\
(6.64)\end{array}$ & $\begin{array}{l}53.33 \\
(7.36)\end{array}$ & 50.83 & 5.53 & 5.69 & 5.16 & 4.60 & 5.42 & 4.60 & 4.90 & 4.20 & 4.40 & 4.52 \\
\hline 0.75 & $\begin{array}{l}33.33 \\
(5.84)\end{array}$ & $\begin{array}{l}36.66 \\
(5.84)\end{array}$ & $\begin{array}{l}26.66 \\
(4.91)\end{array}$ & $\begin{array}{l}30.00 \\
(4.91)\end{array}$ & 31.66 & 5.40 & 5.50 & 5.20 & 1.40 & 5.35 & 1.40 & 1.70 & 1.10 & 1.30 & 1.38 \\
\hline $0.25+0.01$ & $\begin{array}{l}36.66 \\
(6.12)\end{array}$ & $\begin{array}{l}40.00 \\
(6.37)\end{array}$ & $\begin{array}{l}26.66 \\
(5.23)\end{array}$ & $\begin{array}{l}30.00 \\
(5.51)\end{array}$ & 33.33 & 4.90 & 5.00 & 4.56 & 3.43 & 4.79 & 3.43 & 3.83 & 3.10 & 3.40 & 3.44 \\
\hline $0.50+0.01$ & $\begin{array}{l}73.33 \\
(8.61)\end{array}$ & $\begin{array}{l}83.33 \\
(9.17)\end{array}$ & $\begin{array}{l}63.33 \\
(8.01)\end{array}$ & $\begin{array}{l}70.00 \\
(7.94)\end{array}$ & 72.49 & 5.80 & 5.90 & 5.60 & 5.56 & 5.75 & 5.56 & 5.83 & 5.10 & 5.40 & 5.49 \\
\hline $0.75+0.01$ & $\begin{array}{l}43.30 \\
(6.64)\end{array}$ & $\begin{array}{l}50.00 \\
(7.11)\end{array}$ & $\begin{array}{l}40.00 \\
(6.37)\end{array}$ & $\begin{array}{l}46.66 \\
(6.89)\end{array}$ & 44.99 & 5.10 & 5.40 & 5.06 & 3.10 & 5.18 & 3.10 & 3.40 & 2.30 & 2.60 & 2.88 \\
\hline Mean & 42.77 & 49.44 & 36.10 & 41.66 & & 5.29 & 5.43 & 5.09 & 3.38 & & 3.38 & 3.69 & 2.90 & 3.16 & \\
\hline \multicolumn{16}{|l|}{$C D(p \leq 0.05)$} \\
\hline Growth regulator (GR) & & & & & 0.572 & & & & & 0.0648 & & & & & 0.10 \\
\hline Media & & & & & 0.330 & & & & & 0.0374 & & & & & 0.05 \\
\hline Explant & & & & & 0.330 & & & & & 0.0374 & & & & & 0.05 \\
\hline GR $x$ Media & & & & & NS & & & & & 0.0917 & & & & & 0.144 \\
\hline
\end{tabular}

*Values given in the parenthesis are square root transformed values

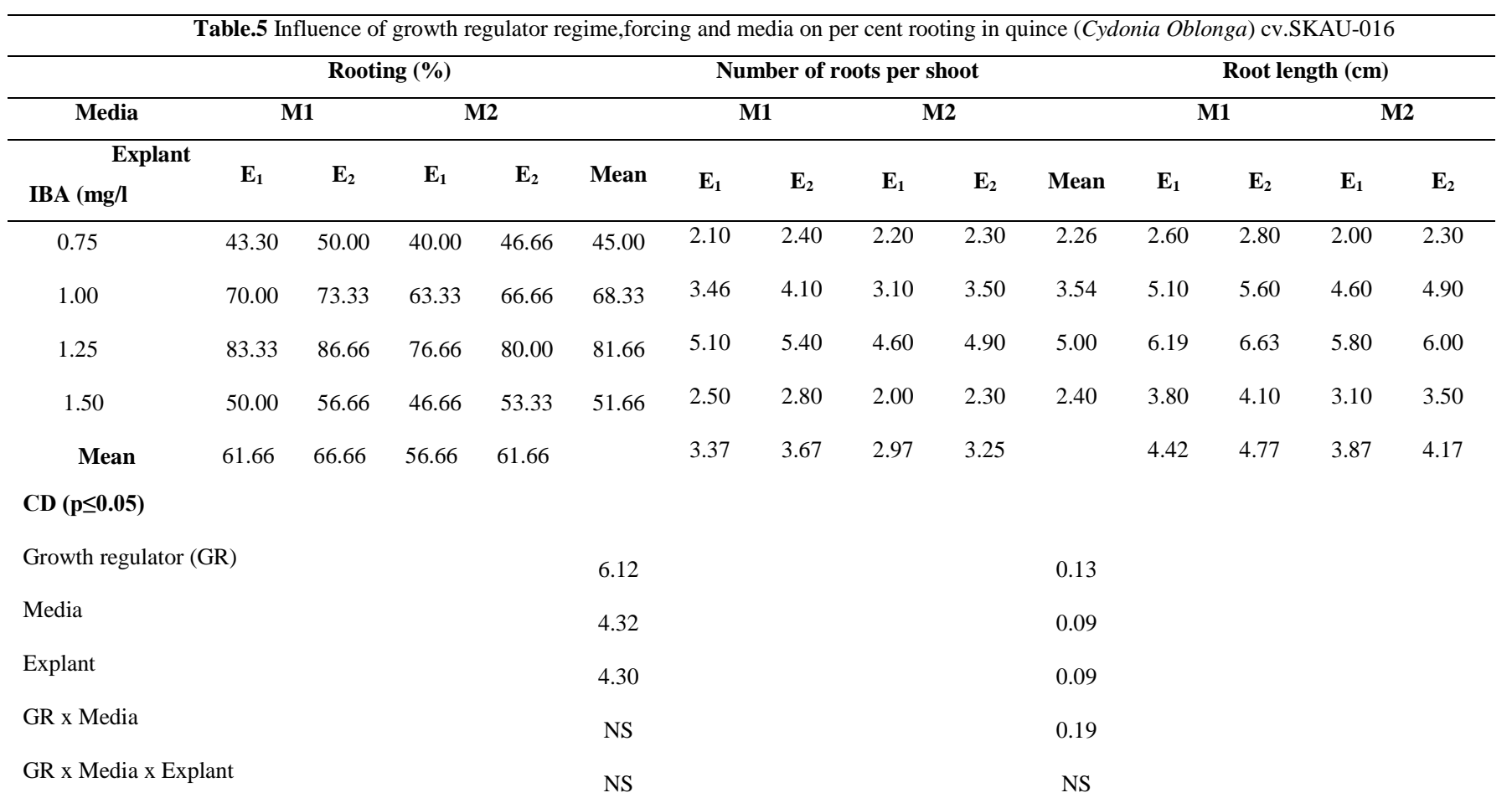




\begin{tabular}{|c|c|c|c|}
\hline \multicolumn{4}{|c|}{$\begin{array}{c}\text { Table.2 Influence of various sterilants on (per cent) } \\
\text { necrotic cultures of quince (Cydonia Oblonga) } \\
\text { cv.SKAU-016 }\end{array}$} \\
\hline \multicolumn{4}{|c|}{ Necrosis (\%) } \\
\hline \multicolumn{4}{|c|}{ Explant Source } \\
\hline Sterilants & Unforced & Forced & Mean \\
\hline $\mathrm{S}_{1}$ & 29.99 & 51.66 & 40.83 \\
\hline $\mathrm{S}_{2}$ & 28.33 & 46.66 & 37.49 \\
\hline $\mathrm{S}_{3}$ & 33.33 & 58.33 & 45.83 \\
\hline $\mathrm{S}_{4}$ & 36.66 & 63.33 & 49.99 \\
\hline $\mathrm{S}_{5}$ & 43.33 & 69.99 & 56.66 \\
\hline Mean & 34.33 & 57.99 & \\
\hline \multicolumn{4}{|l|}{$C D(p \leq 0.05)$} \\
\hline \multicolumn{3}{|c|}{ Main effect of Sterilants } & 1.26 \\
\hline \multicolumn{3}{|c|}{ Main effect of Explant } & 2.00 \\
\hline \multicolumn{3}{|c|}{ Sterilants x Explants } & 2.83 \\
\hline
\end{tabular}

\begin{tabular}{|c|c|c|c|c|c|}
\hline \multicolumn{6}{|c|}{ Explant Establishment (\%) } \\
\hline Media & \multicolumn{2}{|c|}{ M1 } & \multicolumn{2}{|c|}{ M2 } & \multirow[b]{3}{*}{ Mean } \\
\hline Explant & & & & & \\
\hline $\begin{array}{l}\text { Growth Regulator } \\
\text { BAP+IBA (mg/l) }\end{array}$ & $\mathbf{E}_{1}$ & $\mathbf{E}_{2}$ & $\mathbf{E}_{1}$ & $\mathbf{E}_{2}$ & \\
\hline 0.25 & $\begin{array}{l}23.33 \\
(4.91)\end{array}$ & $\begin{array}{l}26.60 \\
(5.23)\end{array}$ & $\begin{array}{l}13.30 \\
(3.73)\end{array}$ & $\begin{array}{l}20.00 \\
(4.48)\end{array}$ & 36.66 \\
\hline 0.50 & $\begin{array}{l}66.66 \\
(8.22)\end{array}$ & $\begin{array}{l}70.00 \\
(8.41)\end{array}$ & $\begin{array}{l}53.33 \\
(7.36)\end{array}$ & $\begin{array}{l}60.00 \\
(7.79)\end{array}$ & 62.49 \\
\hline 0.75 & $\begin{array}{l}23.33 \\
(4.91)\end{array}$ & $\begin{array}{l}26.66 \\
(5.23)\end{array}$ & $\begin{array}{l}16.66 \\
(4.16)\end{array}$ & $\begin{array}{l}20.00 \\
(4.58)\end{array}$ & 21.66 \\
\hline $0.25+0.01$ & $\begin{array}{l}40.00 \\
(6.37)\end{array}$ & $\begin{array}{l}43.33 \\
(6.64)\end{array}$ & $\begin{array}{c}30.00( \\
5.51)\end{array}$ & $\begin{array}{l}33.33 \\
(5.84)\end{array}$ & 36.66 \\
\hline $0.50+0.01$ & $\begin{array}{l}83.33 \\
(9.17)\end{array}$ & $\begin{array}{l}86.66 \\
(9.35)\end{array}$ & $\begin{array}{l}76.66 \\
(8.80)\end{array}$ & $\begin{array}{l}80.00 \\
(8.98)\end{array}$ & 81.66 \\
\hline $0.75+0.01$ & $\begin{array}{l}46.66 \\
(6.89)\end{array}$ & $\begin{array}{l}50.00 \\
(7.11)\end{array}$ & $\begin{array}{l}36.66 \\
(6.12)\end{array}$ & $\begin{array}{l}40.00 \\
(6.37)\end{array}$ & 43.33 \\
\hline Mean & 47.21 & 50.54 & 37.76 & 42.22 & \\
\hline$C D(p \leq 0.05)$ & & & & & \\
\hline Growth regulator (GR) & & & & & 0.49 \\
\hline Media & & & & & 0.28 \\
\hline Explant & & & & & 0.28 \\
\hline
\end{tabular}

Fig.1 Forcing of dormant cuttings

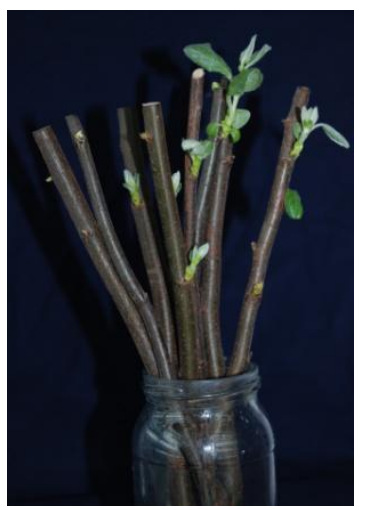

Fig.3 Explant proliferation

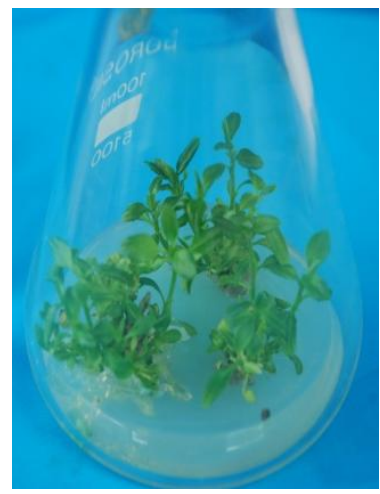

Fig.2 Explant establishment

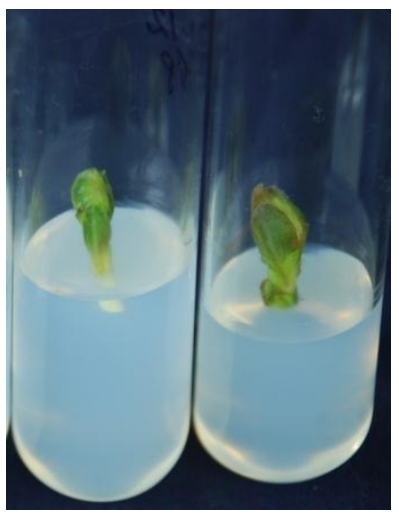

Fig.4 Rooting of micro shoots

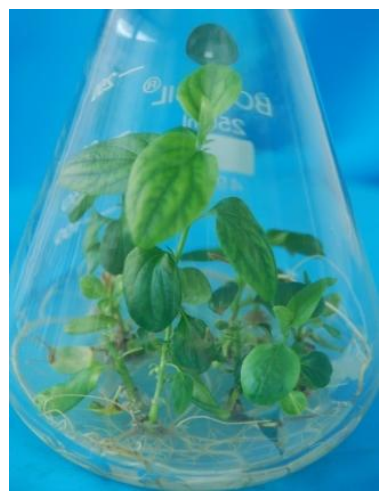




\section{Auxillary shoot proliferation}

Established cultures were transferred to fresh medium supplemented with various concentrations of BAP and IBA for shoot proliferation through stimulation of auxillary buds.

Effect of various concentrations of growth regulators on proliferation per cent of established explants of quince cv. SKAU -016 was highly significant (Table 4). Over all proliferation percentage was increased when cytokinin and auxin were used in combination. Maximum proliferating cultures $(72.49 \%)$ (Fig. 3), highest shoot number lexplants $(5.75 \mathrm{~cm})$ and maximum shoot length $(5.49 \mathrm{~cm})$ was obtained with BAP+IBA $(0.50+0.01 \mathrm{mg} / \mathrm{l})$. Cytokinins are known to promote cyto-differentiation (Fukuda and Komamine, 1985) and eliminate apical dominance (Wickson and Thimann, 1958). Per cent proliferation of established cultures of quince selection was found to be affected by both the application of BAP and IBA. However BAP has been found to be most effective cytokinin for stimulating auxillary shoot proliferation. Results in the present study are in close conformity with Vinter halter and Neskonic (1992) who reported that the best multiplication/proliferation medium was MS supplemented with $4.5 \mu \mathrm{m}$ BA and $0.1 \mathrm{~mm}$ IBA. The observations related to proliferation parameters are in close conformity with number of workers who used combinations of cytokinin (BA) and auxin (IBA) for shoot proliferation and multiplication in quince.MS media proved superior to WPM recording maximum proliferated cultures (49.44\%), shoot number/explants (5.43) and shoot length $(3.69 \mathrm{~cm})$. Erig and Schuch (2004a) also recorded maximum proliferation of quince on MS medium supplemented with $10 \mathrm{mg}^{-1}$ myo Inositol, BAP $13.3 \mu \mathrm{m}$, IAA $0.6 \mu \mathrm{m}$ and $\mathrm{GA}_{3}$ $0.3 \mu \mathrm{m}$. Combination of cytokinin plus auxin for better proliferation in the present studies are in close conformity with Gulsen and Dumanoglu (1991) who obtained better shoot proliferation and shoot development on MS medium supplemented with $3 \mathrm{~g} \mathrm{ml}^{-1} \mathrm{BA}, 0.1$ $\mathrm{mg} \mathrm{l}^{-1} \mathrm{IAA}, 0.1 \mathrm{mg} \mathrm{l}^{-1} \mathrm{GA}_{3}$.

\section{Rooting of microshoots}

During the present study two phase root induction procedure was followed for inducing roots in microshoots of quinceSKAU-016 selection, as this procedure has been found effective in rooting microshoots of apple and peach (Modgil et al., 1994 and Hammerschlag, 1980). Micro shoots were kept in auxin supplemented medium for 10 days for root initiation and then transferred to hormone free medium for root development and elongation. Shootlets from the proliferating cultures were aseptically excised and transferred to the rooting media supplemented with various concentrations of Indole 3 butyric acid (IBA). The shoots were first cultured in IBA supplemented MS and WPM medium for root induction followed by their transfer to the hormone free media for root elongation. All the rooting parameters were significantly influenced by supplementation of MS medium with different concentrations of IBA (Table 5). Maximum mean percentage $(81.66 \%)$ of rooted shoots was observed when IBA was used at $1.25 \mathrm{mg} \mathrm{l}^{-1}$ (Fig. 4) followed by 68.33 $\%$ when IBA was used at $1.0 \mathrm{mg} \mathrm{l}^{-1}$ whereas the lowest percentage of 45.00 was observed when IBA was used at $0.75 \mathrm{mg} \mathrm{l}^{-1}$. As regards the main effect of media it was revealed that maximum mean percentage to the tune of 64.16 per cent was observed when shoots of SKAU-016 were cultured in MS media compared to 59.16 per cent in Lloyd and McCown media.

The main effects due to the media, forcing and different concentrations of Indole-3- 
butyric acid on number of roots per explants was statistically significant. Maximum mean number of roots (5.0 roots/explant) was obtained when IBA was used at $1.25 \mathrm{mg} \mathrm{l}^{-1}$ followed by 3.54 roots/explant at $1.0 \mathrm{mg} \mathrm{l}^{-1}$ IBA, whereas only 2.26 roots/explant were obtained when IBA was used at $0.75 \mathrm{mg} \mathrm{l}^{-1}$. Regarding the main effect of medium it was observed that SKAU-016 under MS medium recorded 3.52 roots/explant as compared to 3.11 roots/explant in case of SKAU-016 under Llyod and Mc Cown medium.

However the maximum mean length of 6.15 $\mathrm{cm}$ was observed when the shoots were cultured in MS medium supplemented with IBA at $1.25 \mathrm{mg} \mathrm{l}^{-1}$ followed by their transfer to hormone free media, whereas the smallest roots of $2.42 \mathrm{~cm}$ length were obtained when IBA was used at $0.75 \mathrm{mg} \mathrm{l}^{-1}$. Trends of the main effect of media reveal that maximum mean length $(\mathrm{cm})$ of roots $(4.59 \mathrm{~cm})$ was observed in case of SKAU-016 when cultured in MS medium as compared to Lloyd and Mc Cown media $(4.02 \mathrm{~cm})$.). Root number and mean root length were significantly influenced by auxin treatment. The shoots inoculated in root induction medium (MS+ IBA at $1.25 \mathrm{mg} \mathrm{l)}$ gave not only maximum percentage and mean number of roots per shoot but also the maximum mean length of the roots whereas increment/ decrement of the IBA concentration resulted in decline of these parameters. These results are in close conformity with Erig and Schuch (2004b) and Giorgota et al., (2009) in quince, Dumanoglu and Gulsen (1994) and Anirudh et al., (2008) in wild pear.

\section{References}

Ahmad, M.F., Sharma, A.K. and Abida, J. 2004. Genetic diversity in quince (Cydonia oblonga Mill.). Indian Horticulture 48(4) : 21.

Anirudh, T., and Kanwar, J.S. 2008.
Micropropagation of wild pear Pyrus pyrifolia (Burm F.) Nakai. 11. Induction of rooting. Hort. Agrobot cluj 36(2) : 104-111.

Bhojwani, S.S., 1990. Plant Tissue Culture. Applications and Limitations. Elsevier, Amsterdam, pp. 461.

Chadha, T.R., 2001. Origin, Classification, Nomenclature and Cultivars. Textbook of Temperate Fruits. ICAR, New Delhi, p. 5.

Dalal, M.A., Kuchey, A.G. and Rather, M.A. 2000. Studies on stock plant treatment and culture initiation in control of browning and media exudation in in vitro culture of apple (Malus domestica Borch.). SKUAST Journal of Research 2 : 10-16.

Dalal, M.A., Sharma, B.B. and Rao, M.S. 1992. Studies on stock plant treatment and initiation culture mode in control of oxidative browning in in vitro culture of grape vine. Scientia Horticulturae 51 : $35-41$.

Dumanoglu, H., and Gulsen, Y. 1994. In vitro rooting of Quince and (Cydonia oblonga Mill.). Acta Horticulturae 367 : 360-363.

Erig, A.C., and Schuch, M.W. 2004a. Effect of the explant orientation in the culture medium, sucrose and agar concentration in the in vitro multiplication of quince shoots (Cydonia oblonga Mill.) cv. M.C. Revista-Cientifica-Rural 9(2): 8088.

Erig, A.C., and Schuch, M.W. 2004b. In vitro rooting of quince cv. MC as rootstock for pear and acclimatization of the rooted micro-cuttings. Ciencia-Rural 34(5): 1443-1449.

Fukuda, H., and Komamine, A. 1985 Cytodifferentiation. In : I.K. Vasil (ed.) Cell Culture and Somatic Cell Genetics of Plants. Vol.2, Academic Press, pp.149-212.

Giorgota, A., Preda, S., Isac, M. and 
Tulvinschi, M. 2009. Established the technology for in vitro propagation of "BN70" and A Type Quince Rootstock of "Aurii" Quince cultivar (Cydonia oblonga Mill.). Acta Horticulturae, 839: 105-109.

Gulsen, Y., and Dumanoglu, H.1991. The effect of sucrose, agar and $\mathrm{pH}$ on shoot multiplication and quality in quince $\mathrm{A}$ micro propagation. Acta Horticulturae 289: 115-116.

Hamerschlag, F.A., 1980. Peach micropropagation. Agricultural Research Results. ARR-NE 118, Beltsville, pp. 48-52.

Modgil, M., Sharma, D.R., Bhardwaj, S.V. and Khosla, K. 1994. In vitro propagation of apple (Malus domestica Borkh.) cv. Golden Delicious. Indian Journal of Horticulture 51(2): 111-118.

Morini, S., and Sciutli, R. 1991. In vitro propagation of quince clonal rootstocks. Agricoltura-Mediterranea, 121(1): 5657
Muna, A.S., Ahmad, A.K., Mahmoud, K. and Abdul Rahman, K. 1999. In vitro propagation of semi-dwarfing cherry rootstock. Plant Cell, Tissue and Organ Culture 59(3): 203-208.

Murashige, T., 1974. Plant propagation through tissue culture. Annual review of plant physiology 25:135-166.

Norton, M.E., and Norton, C.R. 1986. Explant origin as determinant of in vitro shoot proliferation in Prunus and Spiraea. Journal of Horticultural Science 61(1) : 43-48.

Steel, G.D., and Torrie, J,H. 1981.Principles and Procedures of Statistics. McGraw Hill Book Company, Singapore, pp.1130.

Vinterhalter, B., and Neskovic, M. 1992. Factors affecting in vitro propagation of Quince (Cydonia Oblonga Mill.) Indian Journal of Horticulture, 67(1): 39-43.

Wickson, M., and Thimann, K.V. 1958. The antagonism of auxin and kinetin in apical dominance. Plant Physiology, 11: $62-74$

\section{How to cite this article:}

Yusra Ali Basu, M.A. Mir, K.M. Bhatt and Mir, B.A. 2017. In Vitro Propagation of Cydonia oblonga cv. SKAU-016. Int.J.Curr.Microbiol.App.Sci. 6(9): 1865-1873.

doi: https://doi.org/10.20546/ijcmas.2017.609.230 